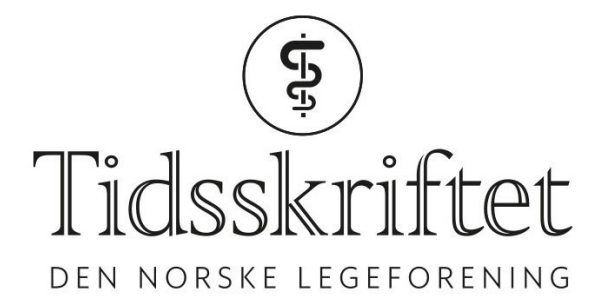

\title{
Khat-tygging kan gi leversykdom
}

FRA ANDRE TIDSSKRIFTER

KRISTOFFER BRODWALL

Barne- og ungdomsklinikken, Haukeland universitetssykehus

Bruk av rusmidlet khat kan gi kronisk leversykdom, spesielt hos menn, ifølge en studie fra Etiopia.

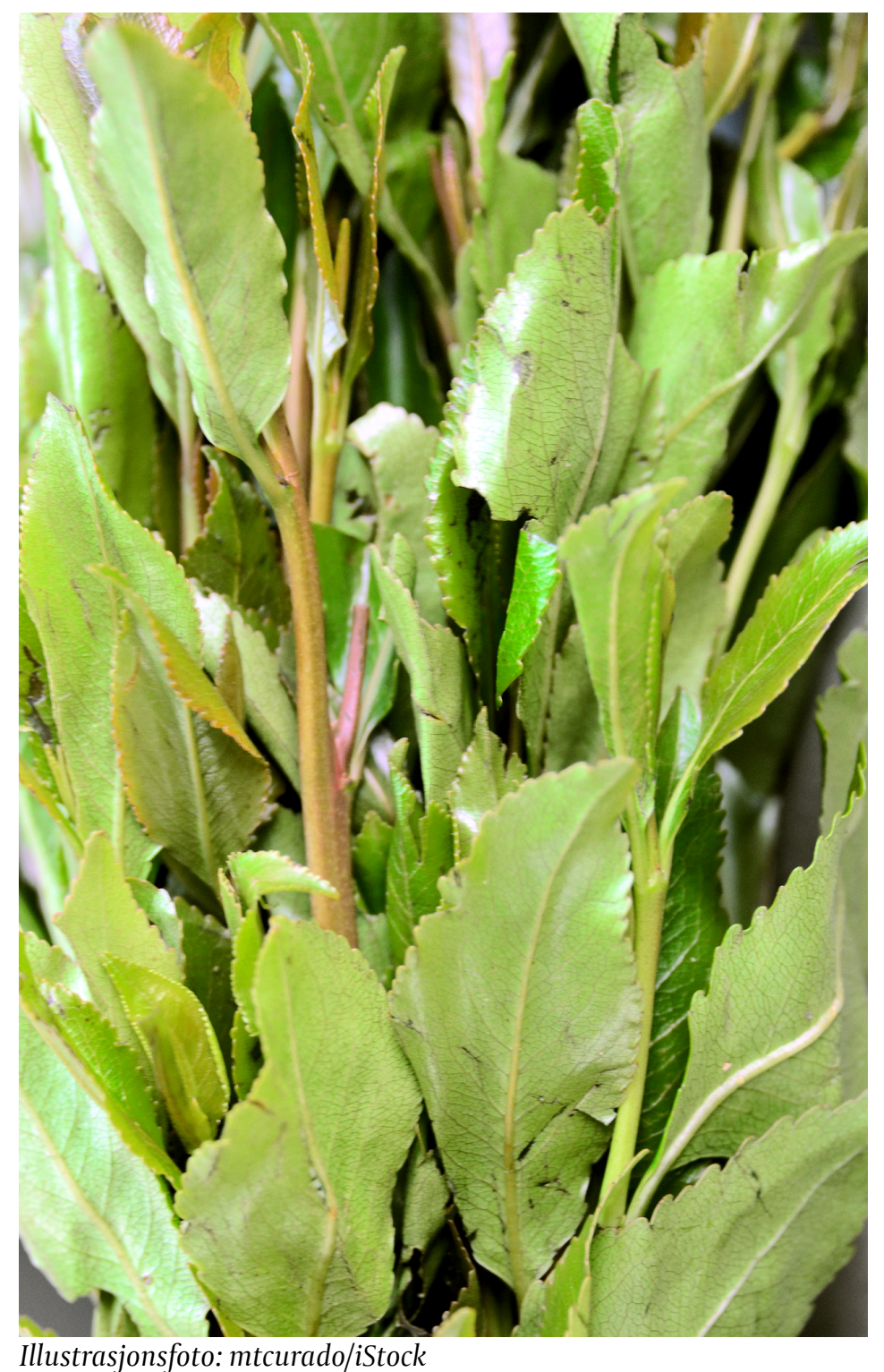


Tygging av blader fra khatplanten (Catha edulis) brukes som rusmiddel, særlig blant menn på Afrikas horn, i Øst-Afrika og på den arabiske halvøy. Ved tygging av khatblader frigjøres alkaloider som fører til eufori og våkenhet, lignende effekten av amfetamin. Kasuistikker tyder på at khat kan gi akutt hepatitt og kronisk leverskade, noe som ble undersøkt nærmere i en pasient-kontroll-studie fra Etiopia, utført av norske og etiopiske forskere (1).

I studien ble bruk av khat kartlagt gjennom intervju av 150 personer med kronisk leversykdom ved to sykehus og 300 leverfriske pasienter med andre sykdommer ved de samme sykehusene. Aktuell eller tidligere bruk av khat ble rapportert av $85 \%$ av dem med leversykdom og $68 \%$ av kontrollpasientene. Bruk av khat var signifikant assosiert med kronisk leversykdom (ujustert oddsratio 2,64; $95 \% \mathrm{KI}$ 1,56-4,58). Blant menn var assosiasjonen enda sterkere og viste en dose-respons-sammenheng med $ø$ kende risiko for leversykdom med økende forbruk av khat: Menn med høyest khat-forbruk hadde en justert oddsratio på 13,03 (95\% KI 3,61-47,02) for utvikling av leversykdom sammenlignet med de som aldri tygde khat, etter justering for alder, alkoholbruk og hepatitt B-infeksjon, etter justering for alder, alkoholbruk og hepatitt B-infeksjon.

Forutsatt at den påviste assosiasjonen er kausal, kan over 80 \% av kronisk leversykdom blant menn i denne regionen forklares med khatbruk. Blant kvinner var ikke assosiasjonen påvisbar. Studien ga ingen forklaring på denne markante kjønnsforskjellen.

Dette er den første epidemiologiske studien som undersøker sammenhengen mellom khat og leversykdom. Resultatene tyder på en sterk og doseavhengig effekt, og tilsier at dette er et stort samfunnshelseproblem i land hvor khat er populært, sier artikkelens førsteforfatter, Stian M.S. Orlien, som er ph.d.-stipendiat ved Oslo universitetssykehus, Ullevål.

LITTERATUR:

1. Orlien SMS, Sandven I, Berhe NB et al. Khat chewing increases the risk for developing chronic liver disease: A hospital-based case-control study. Hepatology 2018; 68: 248 - 57. [PubMed][CrossRef]

Publisert: 17. september 2018. Tidsskr Nor Legeforen. DOI: 10.4045/tidsskr.18.0510

(C) Tidsskrift for Den norske legeforening 2020. Lastet ned fra tidsskriftet.no 